\title{
ANALISIS KESESUAIAN EKOSISTEM MANGROVE SEBAGAI KAWASAN EKOWISATA DI PULAU KELAPAN KABUPATEN BANGKA SELATAN
}

\author{
Arthur Muhammad Farhaby, Andi Abdullah, Carmila, Edward \\ Arnanda, Emi Atika Nasution, Feriyanto, Khudory Mustofa, Lestari \\ Lyadi Putri, Muhammad Mahatir, Novi Santia, Susi Susanti, Sumarli \\ Simamora, Yanti Lestari \\ Jurusan Manajemen Sumberdaya Perairan, Universitas Bangka Belitung, \\ Kepulauan Bangka Belitung, Indonesia \\ E-mail : Amfarhaby88@gmail.com
}

Received June 2020, Accepted August 2020

\begin{abstract}
ABSTRAK
Pulau Kelapan secara geografis terletak pada $2^{\circ} 50^{\prime} 59.000^{\prime \prime}$ LS dan $106^{\circ} 50$ '31.000" BT.Pulau Kelapan terletak di desa Kumbung, Kecamatan Lepar Pongok, Kabupaten Bangka Selatan. Pulau ini dikelilingi oleh hutan mangrove yang masih alami dan keberadaannya memang dijaga oleh masyarakat Pulau Kelapan.Kawasan hutan mangrove Pulau Kelapan memiliki potensi untuk dikembangkan menjadi destinasi ekowisata mangrove. Penelitian ini bertujuan untuk mengetahui kesesuaian lahan mangrove di Pulau Kelapan untuk dikembangkan sebagai lokasi wisata. Data yang diambil meliputi data kesesuaian wisata mangrove seperti parameter vegetasi dan lingkungan. Penelitian ini dilakukan pada bulan November 2019 di Pulau Kelapan, Kabupaten Lepar Pongok, Kabupaten Bangka Selatan. Stasiun pengamatan dalam penelitian ditentukan dengan metode purposive sampling, dimana membagi pulau kelapan ke dalam 4 stasiun pengamatan. Hasil penelitian menunjukkan bahwa Indeks Kesesuaian Wisata (IKW) untuk ekowisata mangrove di Pulau Kelapan pada stasiun 1 termasuk dalam kategori sangat cocok (S1) dengan nilai IKW 79\% dan yang termasuk kategori sesuai (S2) ditemukan di stasiun 2.3 dan 4 dengan nilai IKW masing-masing adalah 51\%, $66 \%$ dan 74\%. Jenis mangrove yang ditemukan di Pulau Kelapan adalah Rhizophora apiculata, Rhizophora mucronata, Xylocarpus granatum yang tersebar di setiap stasiun pengamatan.
\end{abstract}

Kata Kunci : Indeks Kesesuaian Wisata (IKW), Mangrove, Pulau kelapan 


\section{ABSTRACT}

\section{SUITABILITY ANALYSIS OF MANGROVE ECOSYSTEM AS ECOTOURISM AREAS IN KELAPAN ISLAND, SOUTH BANGKA} DISTRICT. The Kelapan Island is geographically located at 2 $50^{\prime} 59,000$ ", LS and 106 $50^{\prime} 31,000$ "BT. Kelapan Island located in the village Kumbung, District Lepar Pongok, South Bangka Regency. The island is surrounded by a natural mangrove forests and its existence is maintained and managed by local communities Kelapan island mangrove forest area has the potential to be developed into a mangrove eco-tourism destination. This study aims to determine the suitability of mangrove area in Kelapan Island to be developed as an ecotourism location. The research data includes the suitability index of mangrove tourism such as vegetation and environmental parameters. This research was conducted on November 2019 on Kelapan Island, Lepar Pongok, South Bangka Regency. The observation stations in the study were determined by the purposive sampling method, which divides the Kelapan islands into 4 observation stations. The results showed that the index of Conformity Tourism (IKW) for ecotourism mangroves on the Kelapan Island at station 1 were included in the category of very suitable (S1) with IKW 79\% and are categorized accordingly (S2) were found in the station 2.3 and 4 with the value of IKW of $51 \%, 66 \%$ and $74 \%$. Mangrove species found on the Kelapan Island was Rhizophora apiculata, Rhizophora mucronata, Xylocarpus granatum found in each observation station.

Keywords : Index of Conformity Tourism (IKW), Mangrove, Kelapan Island

\section{PENDAHULUAN}

Provinsi Kepulauan Bangka Belitung merupakan salah satu provinsi di Indonesia yang dikelilingi oleh perairan, dengan luas wilayah perairan $65.301 \mathrm{~km}^{2}$ mencapai 4 kali dari seluruh luas wilayah daratannya yaitu $16.281 \mathrm{~km}$ (Dinas Kelautan dan Perikanan Provinsi, 2006). Oleh karenanya provinsi tersebut memiliki potensi sumberdaya wilayah peisisr dan laut yang sangat besar dan strategis (Agus salim dan hartoni, 2014). Provinsi Kepulauan Bangka Belitung terdiri dari beberapa pulau dan tesebar di beerbagai daerah provinsi ini, salah satunya ialah pulau Kelapan. Pulau Kelapan secara geografis terletak pada $2^{\circ} 50^{\prime} 59.000^{\prime \prime}$ LS dan 106 50'31.000" BT berdasarkan Direktori Pulau-Pulau Kecil 2018. Secara administrasi Pulau Kelapan terletak di Desa Kumbang, Kecamatan Lepar Pongok, Kabupaten Bangka Selatan, Provinsi Kepulauan Bangka Belitung. Secara demografis Pulau Kelapan memiliki 30 kepala keluarga yang mayoritas penduduknya bermata pencaharian sebagai nelayan. Jumlah penduduk di Pulau Kelapan sebanyak 120 jiwa yang terdiri dari 68 laki-laki dan 52 perempuan (BPS Bangka Selatan, 2019).

Ekowisata didefinisikan sebagai suatu bentuk wisata yang menekan tanggung jawab terhadap kelestarian alam, memberi manfaat secara 
ekonomi dan mempertahankan keutuhan budaya bagi masyarakat setempat. Seiring dengan semakin berkembangnya niat konservasi dan peningkatan kesejahteraan masyarakat, maka lahir definisi baru mengenai ekowisata yaitu suatu bentuk perjalanan wisata ke area alami yang dilakukan dengan tujuan mengkonservasi lingkungan dan melestarikan kehidupan dan kesejahteraan penduduk setempat (Tuwo, 2011).

Hutan mangrove adalah tipe hutan yang khas terdapat di sepanjang pantai atau muara sungai yang dipengaruhi oleh pasang surut air laut. Mangrove tumbuh pada pantai yang terlindung atau pantai yang datar, biasanya di sepanjang sisi pulau yang terlindung dari angin atau di belakang terumbu karang di lepas pantai yang terlindung (Nybakken, 1992). Mangrove juga merupakan kelompok tumbuhan yang dapat tumbuh dengan baik pada kawasan pasang surut di daerah tropis dan subtropis (Farhaby dan Utama, 2019) dan mampu beradaptasi dengan lingkungan yang ekstrim baik suhu yang tinggi, sedimentasi tinggi, salinitas tinggi, pasang surut ekstrim, serta substrat yang kaya oksigen dan tanpa oksigen (Dharmawan dan Pramudji, 2014).

Pemanfaatan ekosistem mangrove untuk konsep wisata (ekowisata) sejalan dengan pergeseran minat wisatawan dari old tourism yaitu wisatawan yang hanya datang melakukan wisata saja tanpa ada unsur pendidikan dan konservasi menjadi new tourism yaitu wisatawan yang datang untuk melakukan wisata yang di dalamnya ada unsur pendidikan dan konservasi (Tuwo, 2011). Melihat potensi mangrove yang sangat besar terdapat di Pulau Kelapan, oleh karena itu pengamatan ini bertujuan untuk mengembangkan pemanfaatan ekosistem mangrove dengan cara mengetahui kesesuian ekowisata mangrove yang ada pada Pulau Kelapan tersebut. Penelitian ini bertujuan untuk mengetahui indeks kesesuaian wisata (IKW) ekosistem mangrove di Pulau Kelapan Kabupaten Bangka Selatan. Penelitian in diharapkan dapat memeberi manfaat bagi beberapa pihak diantaranya ialah (1) Untuk pemerintah, yaitu sebagai informasi dan bahan pertimbangan bagi pemerintah setempat dalam pengelolaan kawasan pariwisata khususnya wisata mangrove di pulau kelapan.(2) Untuk akademisi, yaitu untuk dijadikan bahan dan acuan untuk penelitian selanjutnya terkait potensi lain yang dimiliki oleh Pulau Kelapan.(3) Untuk masyarakat, yaitu dapat memberikan informasi kepada masyarakat mengenai pemanfaatan daerah mangrove yang ada di pulau kelapan.

\section{MATERI DAN METODE}

\section{Materi Penelitian}

Penelitian ini dilaksanakan pada bulan November 2019 bertempat di Pulau Kelapan Kabupaten Bangka Selatan Provinsi Kepulauan Bangka Belitung. Perhitungan data dilakukan di Laboratorium Manajemen Sumberdaya Perairan, Universitas Bangka Belitung. Peta lokasi penelitian dapat dilihat pada Gambar 1. 


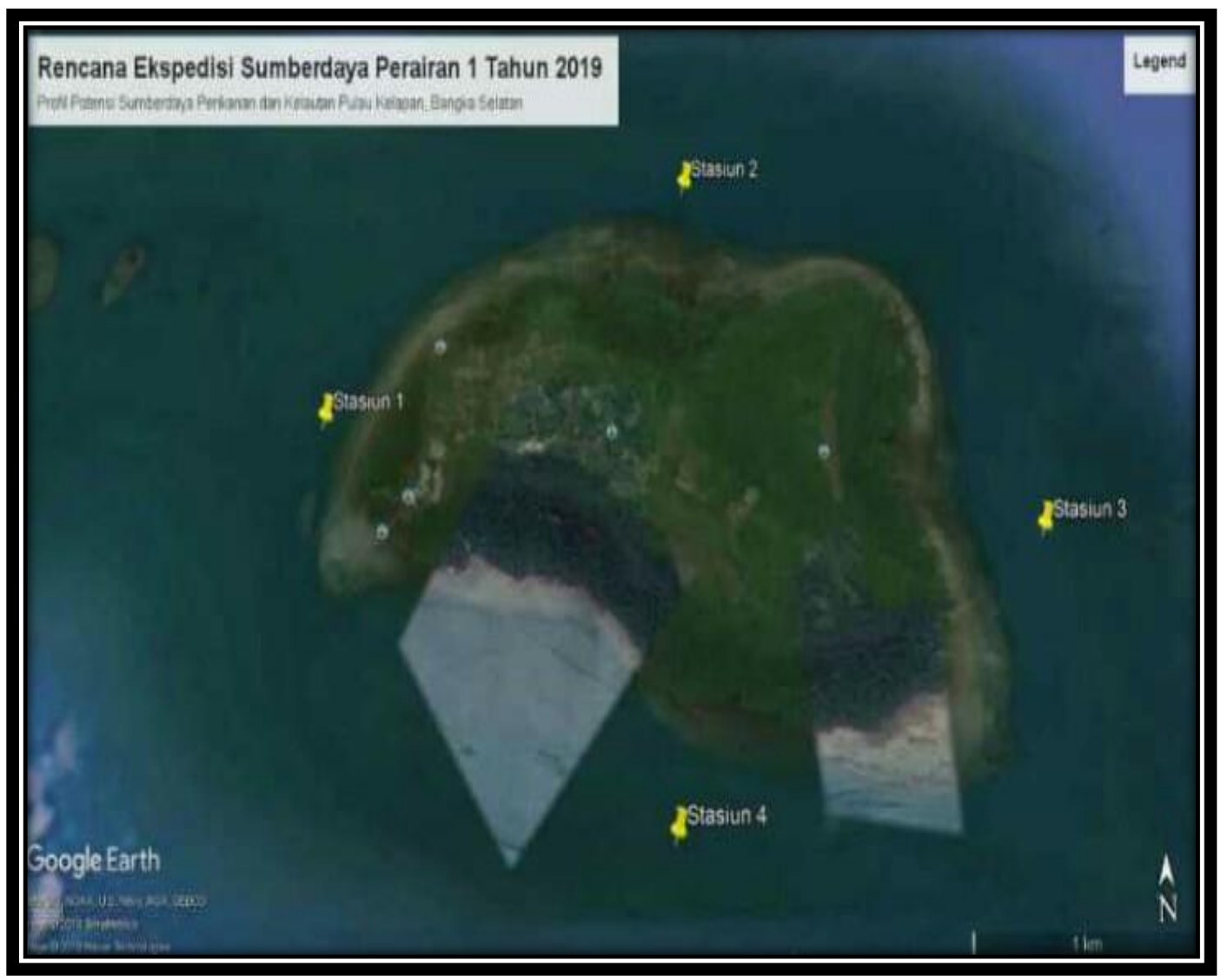

Gambar 1. Peta Lokasi Penelitian

\section{Metode Penelitian}

Dalam penelitian ini, pengambilan data diperoleh dari data primer yaitu data yang langsung diperoleh dari lapangan, meliputi pengukuran ketebalan mangrove, kerapatan mangrove, keanekaragaman jenis mangrove, pasang surut dan obyek biota yang berasosiasi dengan ekosistem mangrove.

\section{Pengumpulan Data Ekosistem Mangrove}

Secara umum pengambilan data ekosistem mangrove dilakukan dengan menggunakan transek garis (line transect). Transek garis yang dibuat dengan cara menarik jalur transek yang menggunakan tali rafia dengan arah tegak lurus dari arah laut ke arah darat sepanjang adanya ekosistem mangrove (Farhaby, 2017).

\section{Pengumpulan Data Obyek Biota}

Data mengenai obyek biota diamati secara visual di lokasi penelitian pada setiap petak/plot misalnya: ikan, udang, kepiting, dan moluska, kemudian ditangkap dengan menggunakan alat tangkap serokan. Setelah didapatkan biota-biota yang ada disetiap petak/plot, 
maka didokumentasikan dengan menggunakan kamera, selanjutnya biotabiota yang ditangkap menggunakan serokan tersebut setelah selesai lalu dilepaskan ke habitatnya semula.

\section{Pengumpulan Data Kualitas Air}

Parameter kualitas air pendukung yang diambil adalah pasang surut. Data pasang surut diperoleh dari data sekunder yang berkaitan dengan pasang surut di Pulau Kelapan Kabupaten Bangka Belitung.

\section{Penentuan Titik Sampling}

Metode penelitian yang digunakan adalah Purposive Sampling yang dibagi 4 stasiun berdasarkan kondisi ekologi Pulau Kelapan. Penelitian dilakukan pada empat stasiun yang berbeda dimana pada setiap stasiun terdapat 1 garis transek dan pada 1 garis transek terdapat 3 petak plot pengambilan sampel.

\section{Indeks Kesesuaian Wisata}

Kesesuaian wisata pantai kategori wisata mangrove mempertimbangkan 5 parameter dengan empat klasifikasi penilaian. Parameter keesuaian wisata pantai kategori wista mangrove antara lain ketebalan mangrove, kerapatan mangrove, jenis mangrove, pasang surut, dan obyek biota

\section{HASIL DAN PEMBAHASAN}

\section{Komposisi Kerapatan dan Ketebalan Mangrove}

Berdasarkan hasil identifikasi tercatat 3 spesies tumbuhan mangrove yang ditemukan pada stasiun penelitian. Dari 3 spesies yang telah didapatkan tidak semua jenis di temukan di dalam stasiun yang sama tetapi kebanyakan dihuni oleh spesies Rhizophora baik itu Rhizophora apiculata maupun Rhizophora mucronata. Hal ini diduga karena kemampuan dari adaptasi mangrove tersebut yang bebrbeda-beda terhadap faktor - faktor lingkungan habitatnya, seperti tipe substrat, fluktuasi salinitas, pasang surut, kandungan bahan organik, suhu dan $\mathrm{pH}$ yang mampu ditoleransi untuk pertumbuhan dari spesies ini. Pada Stasiun 3 dan 4 spesies Rhizophora apiculata maupun Rhizophora mucronata merupakan jenis vegetasi mangrove yang dominan dengan kerapatan mangrove total pada masing masing stasiun tersebut berturut-turut adalah 423 pohon/ha dan 435 pohon/ha. Menurut Bengen (2000) spesies pohon dikatakan dominan jika spesies tersebut terdapat di areal yang bersangkutan dalam jumlah besar, tersebar merata ke seluruh areal dan berdiameter besar. Dijelaskan (Tuwo 2011) bahwa ekosistem mangrove umumnya didominasi oleh tumbuhan dari genera Rhizophora, Avicennia, Sonneratia dan Bruguiera, memiliki kemampuan adaptasi yang khas untuk 
dapat hidup dan berkembang pada substrat berlumpur dan asam, anoksik dan selalu tergenang, kadar garam air yang tinggi, tanah yang kurang stabil dan adanya pasang surut. Komposisi spesies dari masing - masing stasiun disajikan pada (Tabel 1) berikut ini :

Tabel 1. Spesies Mangrove yang ditemukan di lokasi pengamatan

\begin{tabular}{cccccc}
\hline No & Spesies & \multicolumn{4}{c}{ Stasiun } \\
\cline { 3 - 6 } & & $\mathbf{1}$ & $\mathbf{2}$ & $\mathbf{3}$ & $\mathbf{4}$ \\
\hline 1 & Rhizophora apiculata & - & + & + & + \\
2 & Rhizophora mucronata & + & - & + & + \\
3 & Xylocarpus granatum & - & - & - & + \\
\hline
\end{tabular}

Keterangan : + = Ditemukan, - = Tidak Ditemukan

Dominansi dari jenis Rhizophora mucronata dan Rhizophora apiculata kemungkinan disebabkan karena kawasan tersebut memiliki substrat pasir hingga pasir berlumpur yang sangat mendukung pertumbuhan mangrove jenis tersebut. Hal ini dikarenakan untuk spesies Rhizophora apiculata ditemukan mendominasi pada ekosistem dengan substrat pasir berlumpur dan cenderung mendekati ke arah muara (Farhaby, 2017).

\section{Objek Biota pada Ekosistem Mangrove}

Jenis fauna mangrove yang ditemukan di lokasi penelitian selain mangrove itu sendiri menjadi daya tarik wisata mangrove. Jenis fauna mangrove sangat menunjang daya tarik wisata mangrove. Pengamatan jenis fauna mangrove dilakukan secara deskripsi di masing-masing stasiun penelitian, Biota yang terdapat disekitar kawasan ekosistem mangrove saling berinterkasi dengan segala jenis komponen biotik dan abiotik yang menghasilkan suatu hubungan saling ketergantungan satu sama lain. Ketika satu faktor dan faktor lainnya saling mendukung maka ekosistem yang dihasilkan akan sesuai dengan yang diharapkan yang nantinya akan mendatangkan keuntungan pada kesesuaian kawasan tersebut sebagai kawasan ekowisata perairan terkhususnnya kawasan ekowisata mangrove. Ikan glodok (Periophthalmus sp), udang pistol (Alpheus sp), mollusca dan kepiting (Uca sp).

\section{Analisis Indeks Kesesuainan Wisata (IKW) Ekosistem Mangrove}

Berdasarkan hasil pengukuran yang telah diperoleh di lapangan yaitu ada 4 stasiun penelitian. Peneliti menganalisis kesesuian berdasarkan aspek penilaian yang disesuaikan dalam tabel parameter 
kesesuian ekowisata mangrove, perhitungan analisis kesesuaian kawasan berdasarkan (Yulianda, 2007).

Nilai indeks kesesuian kawasan ekowisata mangrove pada (Tabel 5), menunjukan tingkat kelayakan ekowisata mangrove sebagai kesesuian kawasan ekowisata mangrove untuk dijadikan sebagai objek ekowisata. Hal ini memiliki nilai penting terhadap suatu pengelolaan suatu ekowisata. Berdasarkan hasil penelitian analisis kesesuian lokasi penelitian pada Stasiun I didapatkan nilai $79 \%$ kategori S1 (Sangat Sesuai), Stasiun II didapatkan nilai $51 \%$ kategori S2 (Sesuai). Sedangkan Stasiun III didapatkan nilai $66 \%$ kategori S2 (Sesuai). Sedangkan pada Stasiun IV didapatkan nilai $74 \%$ kategori S2 (Sesuai). Hasil analisis data yang didapat menunjukkan bahwa semua lokasi penelitian berada pada tingkat kesesuaian yang bagus (S1-S2). Semua stasiun berada pada kategori sesuai dan satu stasiun berapa pada kategori sangat sesuai, hal ini di dukung oleh beberapa parameter yang saling bergantungan antara yang satu dengan yang lain. Parameter tersebut memiliki nilai yang berbedabeda antara satu parameter dengan yang lainnya di setiap stasiun, oleh karena itu presentasi nilai indeks kesesuaian kawasan wisata mangrove yang diuji menunjukkan nilai yanng berbeda-beda.

Stasiun I didapatkan hasil analisis kesesuian ekowisata mangrove dari 5 parameter diantaranya : ketebalan mangrove $467 \mathrm{~m}$, kerapatan mangrove $35,80\left(\mathrm{Ind} / \mathrm{m}^{2}\right)$, jenis mangrove yaitu 1 jenis yaitu Rhizophora mucronata, pasang surut $(\mathrm{m}) 1,7 \mathrm{~m}$, dan obyek biota yang terdapat di satusiun 1 yaitu ikan, udang, mollusca dan kepiting. Sedangkan pada Stasiun II didapatkan ketebalan mangrove $100 \mathrm{~m}$, kerapatan mangrove 41 $\left(\mathrm{Ind} / \mathrm{m}^{2}\right)$, jenis mangrove 1 jenis yaitu Rhizophora apiculata, pasang surut $1,7 \mathrm{~m}$ dan obyek biota yang ditemukan diantaranya yaitu ikan dan mollusca. Selanjutnya pada Stasiun III didapatkan hasil analisis kesesuaian ekowisata mangrove dengan ketebalan mangrove $423 \mathrm{~m}$, kerapatan mangrove $74\left(\mathrm{Ind} / \mathrm{m}^{2}\right)$, jenis mangrove 2 jenis yaitu Rhizophora apiculata dan Rhizophora mucronata, pasang surut $1,7 \mathrm{~m}$, dan obyek biota yang didapatkan pada stasiun ini diantaranya ikan, mollusca, kepiting dan udang. dan pada stasiun 4 didapatkan hasil analisis kesesuaian ekowisata mangrove dengan ketebalan mangrove $345 \mathrm{~m}$, kerapatan mangrove $96\left(\mathrm{Ind} / \mathrm{m}^{2}\right)$, jenis mangrove 3 jenis yaitu Rhizophora apiculata, Rhizophora mucronata dan Xylocarpus granatum, pasang surut 1,7 $\mathrm{m}$, dan obyek biota yang didapatkan pada stasiun ini diantaranya ikan, mollusca, kepiting dan udang. Menurut Farhaby (2017) Ekosistem mangrove merupakan ekosistem penting untuk berbagai jenis biota yang hidup disekitarnya. Ekosistem mangrove dapat dijadikan sebagai tempat mencari makan dan berkembang biak ikan dan gastropoda yang berasosiasi dikawasan mangrove tersebut. Hal ini sesuai dengan Nybakken (1992) yang menyatakan bahwa ikan menjadikan mangrove sebagai tempat untuk pemijahan, habitat permanen atau tempat berkembang biak.

Hutan mangrove adalah tipe hutan yang khas terdapat di sepanjang pantai atau muara sungai yang dipengaruhi oleh pasang surut air laut. Mangrove tumbuh pada pantai yang terlindung atau pantai yang 
datar, biasanya di sepanjang sisi pulau yang terlindung dari angin atau di belakang terumbu karang di lepas pantai yang terlindung (Nybakken, 1992). Mangrove juga merupakan kelompok tumbuhan yang dapat tumbuh dengan baik pada kawasan pasang surut di daerah tropis dan subtropis (Nontji, 2002) dan mampu beradaptasi dengan lingkungan yang ekstrim baik suhu yang tinggi, sedimentasi tinggi, salinitas tinggi, pasang surut ekstrim, serta substrat yang kaya oksigen dan tanpa oksigen (Dharmawan dan Pramudji, 2014).

Pemanfaatan ekosistem mangrove untuk konsep wisata (ekowisata) sejalan dengan pergeseran minat wisatawan dari old tourism yaitu wisatawan yang hanya datang melakukan wisata saja tanpa ada unsur pendidikan dan konservasi menjadi new tourism yaitu wisatawan yang datang untuk melakukan wisata yang di dalamnya ada unsur pendidikan dan konservasi (Fitriana et al, 2011). Melihat potensi mangrove yang sangat besar terdapat di Pulau Kelapan, oleh karena itu pengamatan ini bertujuan untuk mengembangkan pemanfaatan ekosistem mangrove dengan cara mengetahui kesesuian ekowisata mangrove yang ada pada Pulau Kelapan tersebut.

\section{Parameter Fisika Kimia Perairan Ekosistem Mangrove}

\section{Suhu}

Pengamatan yang dilakukan di perairan Pulau Kelapan didapatkan suhu rata - rata $30^{\circ} \mathrm{C}$ dari ke 4 stasiun yang diuji. Menurut Farhaby (2019), efektifitas suhu yang dapat ditolerir oleh berbagai jenis tumbuhan mangrove berapa pada rentan antara $25^{\circ} \mathrm{C}-45^{\circ} \mathrm{C}$ sedangkan suhu yang dapat ditolerir oleh makrozoobenthos yang berasosiasi dengan tumbuhan mangrove ini dalam hidup dan kehidupannya dengan lingkungan berkisar antara $25^{\circ} \mathrm{C}-53^{\circ} \mathrm{C}$. Hasil pengukuran menunjukkan bahwa suhu berada pada nilai $30^{\circ} \mathrm{C}$ dari setiap masing-masing stasiun, hal ini mengindikasikan bahwa tumbuhan mangrove yang ada pada setiap stasiun masih dapat mentolerir suhu yang masuk ke dalam ekosistem tersebut karena masih berada pada kisaran $25^{\circ} \mathrm{C}-45^{\circ} \mathrm{C}$ oleh karenanya tumbuhan mangrove ini masih dapat tumbuh dan berkembang secara normal seperti biasanya. Suhu sangat dipengaruhi oleh intensitas cahaya yang masuk ke dalam suatu ekosistem sehingga tinggi rendahnya suhu erat kaitannya dengan tinggi rendahnya intensitas cahaya yang masuk ke dalam suatu ekosistem. Hal ini sesuai dengan pernyataan (Nontji, 2002).

\section{Kecerahan dan Kedalaman}

Menurut Sembiring (2008), menyatakan bahwa faktor yang mempengaruhi kecerahan adalah kejernihan yang sangat ditentukan partikel-pertikel terlarut dalam lumpur. Semakin banyak partikel atau bahan organik terlarut maka kekeruhan akan meningkat. Kekeruhan atau konsentrasi bahan tersuspensi dalam perairan akan menurukan efisiensi makan dari organisme. Hasil pengukuran menggambarkan bahwa 
kecerahan ekosistem mangrove ini sebesar 100\%, hal ini dapat diartikan bahwa perairan tersebut sangat jernih. Sedikitnya bahan organik dan pertikel yang terlarut dalam perairan menyebabakan kawasan ekosistem mangrove ini sangat jernih, sesuai dengan pernyataan (Sembiring, 2008). Berdasarkan hasil data yang diperoleh selama penelitian di dapatkan hasil kedalaman yaitu $48-86 \mathrm{~cm}$ yang mewakili kedalaman disetiap stasiunnya. Kedalaman suatu perairan berhubungan erat dengan produktivitas, suhu vertikal, penetrasi cahaya, densitas, kandungan oksigen, serta unsur hara.

\section{Salinitas}

Menurut Bengen (2000), masing-masing jenis mangrove memiliki toleransi yang berbeda terhadap tingginya salinitas lingkungan, batas ambang toleransi tumbuhan mangrove diperkirakan mencapai batas $90 \%$, kadar salinitas disekitar hutan mangrove tergantung dari bertambahnya volume air tawar yang mengalir dari sungai dan salinitas tertinggi terjadi pada musim kemarau. Kisaran salinitas yang masih mampu mendukung kehidupan organisme perairan, khususnya fauna kehidupan organisme perairan, khususnya fauna makrozoobenthos adalah 15 - 35 ppt. Dari hasil pengamatan diperoleh pengukuran salinitas berada pada kisaran 30 ppt. Nilai salinitas ini masih dapat ditolerir oleh mangrove dan biota yang ada di dalamnya karena masih berada pada rentang 15-35 ppt. Tingginya nilai salinitas terutama dipicu oleh faktor suhu yang semakin meningkat. Ketika suhu semakin meningkat maka penguapan atau evaporasi di dalam perairan akan semakin meningkat juga sehingga kadar garam yang tertinggal akibat penguapan akan semakin tinggi sehingga semakin tinggi suhu semakin tinggi salinitas di suatau kawasan perairan. Hal ini sesuai dengan pernyataan (Farhaby 2017).

\section{Derajat Keasaman}

Data $\mathrm{pH}$ yang didapatkan dari pengamatan di desa Kurau Timur berkisar 8 untuk $\mathrm{pH}$ diperairan ini sangat baik.karena Nilai yang ideal bagi kehidupan tumbuhan mangrove pada umumnya terdapat pada kisaran nilai 7 sampai 8,5 . Kondisi perairan yang bersifat sangat asam maupun sangat basa akan membahayakan kelangsungan hidup organisme karena akan menyebabkan terjadinya gangguan metabolisme dan respirasi.

Menurut (Koch, 2001) jika pH rendah maka akan terjadi dekomposer yang mengakibatkan proses perombakan bahan organik menjadi anorganik lambat dan sebaliknya jika $\mathrm{pH}$ tinggi maka proses perombakan untuk menjadi bahan anorganik cepat. Dalam data pengamatan ini nilai $\mathrm{pH}$ sesuai yang membuat pertumbuhan vegetasi mangrove di Pulau Kelapan baik dikarenakan pasokan unsur hara dan mineral yang mencukupi. 


\section{DO}

Berdasarkan data dari pengukuran DO di perairan ekosistem mangrove di perairan Pulau Kelapan menunjukkan bahwa oksigen terlarut berada pada kisaran angka 4 - 5,9 ppm, hal ini disebabkan oleh adanya perbedaan suhu. Peningkatan suhu akan penyebab konsentrasi oksigen akan menurun dan sebalikanya yang rendah akan meningkatkan konsentrasi oksigen terlarut.oksigen terlalut didalam air bersumber terutama dari adanya kontak antara permukaan air dengan udara dan dari proses fotosintesis.

Tingginya angka dari oksigen terlarut dalam perairan menyebabkan aktifitas dari fotosintesis fitoplanton yang tidak maksimal. Karena kekeruhan yang tinggi sehingga kegiatan fotosintesis terganggu, mengingat pengambilan data pada saat pasang dengan kondisi perairan keruh selain itu suhu air yang tinggi dapat meningkatkan kecepatan metabolisme hewan air dengan meningkatkan respirasi sehingga dapat menurunkan jumlah dari oksigen terlarut (Cahyani, 2001).

\section{Arus}

Kecepatan arus di lokasi penelitian berkisar antara 0,021 - 0,037 $\mathrm{m} / \mathrm{s}$. Kecepatan arus secara tak langsung akan mempengaruhi substrat dasar perairan. Menurut Nontji (2002), berdasarkan kecepatannya maka arus dapat dikelompokkan menjadi arus sangat cepat ( $>1 \mathrm{~m} / \mathrm{dt}$ ), arus cepat $(0,5-1 \mathrm{~m} / \mathrm{dt})$, arus sedang $(0,1-0,5 \mathrm{~m} / \mathrm{dt})$, dan arus lambat $(<0,1$ $\mathrm{m} / \mathrm{dt}$ ). Dari pengelompokkan tersebut didapatkan bahwa kondisi arus dilokasi penelitian masuk dalam kategori lambat, hal ini disebabkan karena sebelum gelombang sampai ke kawasan ekosistem mangrove sudah tertahap oleh ekosistem terumbu karang dan juga ekosistem lamun sehingga semakinmenuju kawasan ekosistem mangrove semakin lama akan semakin kecil.

\section{KESIMPULAN}

Stasiun 1 memiliki nilai IKW sebesar $79 \%$, Stasiun 2 memiliki nilai IKW sebesar $51 \%$, Stasiun 3 memiliki nilai IKW sebesar $66 \%$ dan Stasiun 4 memiliki nilai IKW sebesar $74 \%$ yang masuk dalam kategori sangat sesuai dan sesuai untuk dijadikan kawasan ekowisata.

\section{DAFTAR PUSTAKA}

Agus salim, Andi dan Hartoni. 2014. Potensi Kesesuaian Mangrove Sebagai Daerah Ekowisata di Pesisir Muara Sungai Musi Kabupaten Banyuasin. Program Studi Ilmu Kelautan, Fakultas MIPA, Universitas Sriwijaya, Palembang. Maspari Journal, Vol. 6, No. 2.

Badan Pusat Statistik Kabupaten Bangka Selatan. 2019. Kabupaten Bangka Selatan Dalam Angka. Toboali : Badan Pusat Statistik. 
Bengen, D. G. 2000. Sinopsis Ekosistem dan Sumberdaya Alam Pesisir. Bogor: IPB.

Cahyani, L. E. 2001. Kualitas Fisik, Kimia, Dan Biologi Perairan Donan Sekitar Buangan Holding Basin Industri Pengelola Minyak Pertamina Cilacap Jawa Tengah. Jurusan Kimia Falkultas Matematika Dan IImu Pengetahuan Alam, Institute Pertanian Bandung.

Dharmawan, I.W.E. \& Pramudji. 2014. Panduan Monitoring Status Ekosistem Mangrove. COREMAPCTI. Pusat Penelitian Oseanografi. Lembaga IImu Pengetahuan Indonesia.

Dinas Perikanan dan Kelautan Propinsi Bangka Belitung. 2006. Pangkalan Pendaratan Ikan. Dinas Perikanan dan Kelautan Propinsi Bangka Belitung.

Farhaby, A. M. (2017). Kajian Karakteristik Biometrika Kepiting Bakau (Scylla sp) di Kabupaten Pemalang, Studi kasus di Desa Mojo Kecamatan Ulujami. Akuatik: Jurnal Sumberdaya Perairan, 11(1).

Farhaby, A. M., \& Utama, A. U. 2019. Analisis Produksi Serasah Mangrove Di Pantai Mang Kalok Kabupaten Bangka. Jurnal Enggano, 4(1), 1-11.

Fitriana, Dessi. Yar Johan, dan Person Pesona Renta. 2016. Analisis Kesesuaian Ekowisata Mangrove Desa Kahyapu Pulau Enggano. Program Studi IImu Kelautan Fakultas Pertanian Universitas Bengkulu, Bengkulu. Jurnal Enggano Vol. 1, No. 2.

Koch, E. 2001. Beyon Light: Physical, Biological, And Geohcemical Parameters As Possible Submersed Aquatic Vegetation Habitat Requirements. Estuaries. 24: 1-17. Kurniawana A.,Sari Pus.

Nontji, A. 2002. Laut Nusantara. Jakarta: Djambatan.

Nybakken, J. W. 1992. Biologi Laut Suatu Pendekatan Biologis. PT Gramedia : Jakarta.

Sembiring, H. 2008. Keanekaragaman dan Kelimpahan Ikan serta Kaitannya Dengan Faktor Fisika Kimia.

Tuwo, A. 2011. Pengelolaan Ekowisata Pesisir dan Laut. Brilian Internasional : Surabaya.

Yulianda,F.2007.Ekowisata Bahari sebagai Alternatif Pemanfaatan Sumberdaya. Fakultas Perikanan dan IImu Kelautan IPB. Bogor. 